\title{
SERVICE-ORIENTED ORGANIZATIONAL CITIZENSHIP BEHAVIOR, SERVICE QUALITY AND CUSTOMER CITIZENSHIP BEHAVIOR: COMPARISON OF IMPLEMENTATION AND EVALUATION FROM THE PERSPECTIVE OF BANK CUSTOMERS
}

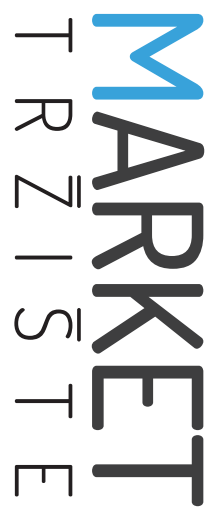

\section{USLUŽNO ORIJENTIRANO ORGANIZACIJSKO PONAŠANJE PREMA GRAĐANIMA, KVALITETA USLUGE I PONAŠANJE KORISNIKA KAO DOBRIH GRAĐANA: USPOREDBA PRIMJENE I PROCJENA IZ PERSPEKTIVE KORISNIKA BANKE}

\section{Soni Harsono a ${ }^{\text {, Harry Widyantorob }}{ }^{\mathrm{b}}$, Tjahjani Prawitowatic, Basuki Rachmat ${ }^{\mathrm{d}}$}

a STIE Perbanas Surabaya, Department of Management, Nginden Semolo Street 34-36, Surabaya, INDONESIA, e-mail: soni@ perbanas.ac.id

bSTIE Perbanas Surabaya, Department of Management, Nginden Semolo Street 34-36, Surabaya, INDONESIA, e-mail: harry@ perbanas.ac.id

c STIE Perbanas Surabaya, Department of Management, Nginden Semolo Street 34-36, Surabaya, INDONESIA, e-mail: tjahjani@perbanas.ac.id

d STIE Perbanas Surabaya, Departement of Management, Nginden Semolo Street 34-36, Surabaya, INDONESIA, e-mail: basuki@perbanas.ac.id

\section{Abstract}

Purpose - This study aims to explore the effect of service-oriented organizational citizenship behavior (SOCB) on service quality and to Compare SOCB, service quality, and customer citizenship behavior (CCB) between two banks.

\section{Sažetak}

Svrha - Cilj je rada otkriti učinak uslužno orijentiranog organizacijskog ponašanja prema građanima (SOCB) na kvalitetu usluge i usporediti SOCB, kvalitetu usluge i ponašanje korisnika kao dobrih građana (CCB) između dvije banke. 
Design/Methodology/Approach - The research method is an associative and comparative approach involving 271 bank customers and 30 bank employees in a survey, using a questionnaire as the primary data collection tool. The analytical tool used is linear regression, with the Mann-Whitney employed to test the data from two independent samples.

Findings and implications - This study proves that SOCB has a significant positive effect on service quality in all banks. There is no observable difference in SOCB, service quality, or CCB assessment between the bank whose employees are given training and the bank whose employees are not given training. There is an increase in employee knowledge after attending the training, specifically an increase in the SOCB score. Changes in employee behavior and skills related to SOCB and service quality can also be observed.

Limitations - This study focuses on SOCB and service quality only while not examining the relationship between satisfaction and CCB, which should be done in theory. The number of research participants is not the same for the two banks.

Originality - While the research study begins with customer evaluation of the banking employees' SOCB and service quality, its results are then taken into consideration in training. The training results are finally re-evaluated by customers and compared with other banks.

Keywords - service-oriented organizational citizenship behavior, service quality, customer citizenship behavior
Metodološki pristup - Korišten je asocijativni i komparativni pristup u istraživanju koje je obuhvatilo 271 korisnika usluge i 30 zaposlenika banke. Primarni podatci prikupljeni su pomoću anketnog upitnika. Kao analitički alat korištena je linearna regresija, a podatci iz dvaju nezavisnih uzoraka ispitivani su primjenom Mann-Whitneyjeva testa.

Rezultati i implikacije - Istraživanje dokazuje da uslužno orijentirano organizacijsko ponašanje prema građanima ima značajan pozitivan učinak na kvalitetu usluge u svim bankama. Ne postoji razlika u procjeni uslužno orijentiranog organizacijskog ponašanja prema građanima, kvalitete usluge ili ponašanja korisnika kao dobrih građana između banke čiji zaposlenici prolaze i banke čiji zaposlenici ne prolaze obuku. Znanje zaposlenika povećava se nakon pohađanja obuke, a posebno se povećava rezultat uslužno orijentiranog organizacijskog ponašanja prema građanima. Postoje promjene u ponašanju i vještinama zaposlenika u vezi s uslužno orijentiranim organizacijskim ponašanjem prema građanima i kvalitetom usluge.

Ograničenja - Istraživanje je usredotočeno samo na uslužno orijentirano organizacijsko ponašanje prema građanima i kvalitetu usluge te ne ispituje odnos između zadovoljstva i ponašanja korisnika kao dobrih građana, što bi teoretski trebalo učiniti. Broj sudionika istraživanja nije jednak za dvije banke.

Doprinos - Istraživanje polazi od korisnikove procjene uslužnog organizacijskog ponašanja zaposlenika banke prema građanima i kvalitete usluge. Rezultati procjene uzeti su u obzir za vrijeme obuke. Korisnici usluge konačno preispituju rezultate obuke i uspoređuju ih s drugim bankama.

Ključne riječi - uslužno orijentirano organizacijsko ponašanje prema građanima, kvaliteta usluge, ponašanje korisnika kao dobrih građana 


\section{INTRODUCTION}

In general, all business activities are aimed at creating satisfaction for customers because satisfaction will create loyalty, positive word-ofmouth, repurchase, and defense from customers, thus ultimately improving the company's financial performance. Service quality is a factor that can create customer satisfaction. In practice, however, some companies have succeeded in creating and implementing quality services while others have failed. These two poles have attracted interest from many researchers. According to Gronroos (1984), the dimensions of service quality consist of: (a) technical quality (what the customers get) and (b) functional quality (how the customers get it). There are 22 determinants of service quality that are summarized in five dimensions: tangibility, reliability, responsiveness, assurance, and empathy (Parasuraman, Zeithaml \& Berry, 1988).

Research conducted by Gomez, McLaughlin and Wittink (2004) concludes that the impact of service quality is higher customer satisfaction. Satisfaction is created if the gap in service quality is very small (Zeithaml, Berry \& Parasuraman, 1988). Superior organizational performance can come from superior service quality (Daskalopoulou \& Petrou, 2005). According to Jalil and Rahman (2014), factors that influence customers to be willing to accept sharia banking services, especially for Muslims, are products and services, reliability, and availability of outlets.

Service quality is generally managed by focusing more on the customer only and forgetting or not realizing who actually manages and provides quality service to customers. Consciously or unconsciously, service quality is created because there are employees who faithfully do things intended to satisfy their customers. As outlined by O'Neill and Palmer (2003), most studies relating to service quality issues have only focused on the customer or the company perspective, with only a few focusing on employee perspectives or combining the employee and the customer perspective in the context of service quality.
Research on service quality has shown the importance of testing the behavior of customers and employees when managing service quality (de Jong, de Ruyter \& Lemmink, 2005). Another factor that is also important for researchers to note in relation to customer satisfaction and loyalty is the behavior of employees who interact directly with business activities, also referred to as organizational citizenship behavior. It is defined as the behavior exhibited by employees that goes beyond their obligations and responsibilities without expecting any reward from the organization, which is aimed solely at the benefit of the organization. Such behavior is a specific aspect that supports marketing in the service sector and plays a role in improving service to customers (Sabiote \& Roman, 2005; Kumar, 2014). Such behavior of employees can increase customer satisfaction (Kumar, 2014). Behavior that goes beyond this role is called service-oriented citizenship behavior (SOCB), which contributes to managing relationships between companies and customers, shapes customer perceptions about excellent service quality, and raises customer loyalty. Thus, it can be concluded that the dimensions of SOCB consist of customer facilitation, organizational involvement, and sportsmanship (Jain, Malhotra \& Guan, 2012). Companies must create and maintain an appropriate service atmosphere so that employees can effectively provide good service.

Research by Harsono, Widyantoro, Prawitowati and Rachmat (2017) identified six dimensions of SOCB that have a significant effect on service quality at Bank Pembangunan Daerah (BPD) and Bank Perkreditan Rakyat (BPR). Employees tend to provide excellent service to customers when companies value their behavior and develop practices that facilitate increased service delivery (Schneider, Ehrhart, Mayer, Saltz \& Niles-Jolly, 2005). The SOCB of the employees of BPD and BPR has a significant positive effect on service quality (Harsono, Widyantoro, Prawitowati \& Rachmat, 2019).

The present study is a follow-up study of BPD and BPR employees related to SOCB and service 
quality, which demonstrated a significant positive effect of SOCB on service quality. However, several indicators of service quality and SOCB showed unfavorable values, which were confirmed by BPD management. The results of the study were not much different from the current conditions. Based on these facts, BPD requested training for its employees. During the training, an assessment was conducted. After completing training, trained employees were assessed again by asking for opinions from customers who were familiar with the employees.

The purpose of this study is: (1) to find out the relationship between SOCB and service quality from the perspective of the customers of BPD, whose employees were provided with training, and the customers of BPR, whose employees were not provided with training; and (2) to conduct different tests of the contribution of SOCB to service quality and customer citizenship behavior at BPD and BPR.

\section{LITERATURE REVIEW}

\subsection{Service quality}

Service quality is defined by Zeithaml, Parasuraman and Dan (1990)) as the extent of discrepancy between customers' expectations or desires and their perceptions. According to Zeithaml and Bitner (2003), service quality is a focused evaluation that reflects the customer's perception of specific dimensions of service consisting of reliability, responsiveness, assurance, empathy, tangibles. Tjiptono and Chandra (2011) state that service quality is a dynamic condition related to whether products, services, human resources, processes, and the environment meet or exceed expectations. The debate about service quality will be endless. However, all researchers agree that if service quality is implemented properly and consistently, it will create customer loyalty, which will ultimately have an impact on business continuity. According to Gronroos (1984), there are two dimensions of service quality to create loyalty: (1) technical quality (what the customers get) and (b) functional quality (how the customers get it). Furthermore, Garvin (1984) states that to create customer loyalty, management must implement service quality well and consistently, so that the dimensions of service quality put forward are performance, features, reliability, conformance, durability, serviceability, aesthetics, and perceived quality.

Parasuraman et al. (1988) modified the service quality concept based on previous studies by reducing the dimensions of service quality from ten to five: (1) responsiveness, (2) assurance, (3) empathy, (4) tangible, and (5) reliability. Cronin and Taylor (1992) explained that service quality could be measured by the service performance (SERVPERF) scale using the SERVQUAL dimensions. Rust and Oliver (1994) proposed to measure service quality using the dimensions of service product, service delivery, and service environment.

According to Brady and Cronin (2001), the main dimensions of service quality are interaction quality (contacts occurring between service providers and consumers in the process of service delivery), environment quality, and outcome quality. According to Gronroos (2000), interaction quality is the quality that is closely related to the manner in which service is delivered, which is seen from the aspect of interaction between service provider employees and their customers. Castro, Armario and Ruiz (2004) provided insight into the financial consequences of service quality. Their findings show that there are many possible moderators of organizational performance. Even in the same company, heterogeneity between branches accounts for a significant difference in profitability. However, service quality contributes to increasing the level of performance because it increases customer loyalty.

\subsection{Service-oriented organizational citizenship behavior}

SOCB is an important aspect in creating service quality. For company management, therefore, SOCB is one of the key factors enabling employ- 
ees to contribute and commit to carrying out basic tasks and other tasks in serving customers. Referring to research conducted by Organ (1988), organizational citizenship behavior is defined as discretionary work behaviors that are not explicitly recognized in the formal reward system and which are carried out voluntarily to support organizational effectiveness and efficiency beyond the call of duty.

The question in the researchers' recent discussion regarding SOCB is the same as that posed by Ryan and Ployhart (2003): namely, whether this behavior, in the service context, is determined by the roles beyond the formal role requirements. In their research in the banking sector, Sabiote and Roman (2005) developed organizational citizenship behavior instruments from the customer perspective. The dimensions of organizational citizenship behavior they offered are customer facilitation, organizational involvement, and sportsmanship. Research by Schneider et al. (2005) revealed that employees not only exhibit behavior but are also involved in the roles oriented at customers, and behaviors that go beyond the tasks and calls to promote high levels of customer satisfaction.

\subsection{Customer citizenship behavior}

In a climate of increasingly fierce competition, banks in their activities must be able to cause emotional attachment to their customers, motivating customers to voluntarily engage in activities outside their basic customer role; this is what is called customer citizenship behavior (CCB).

Customers who have loyalty to a particular bank will not only carry out their routine transactions in the long run and remain customers who entrust their financial activities to the bank, but also display behavior which goes beyond their role as customers of the bank. According to Di, Huang, Chen and Yu (2010), there are four dimensions of loyalty: altruism, conscientiousness, courtesy, and civic virtue. In the context of banking organizations, altruism is the willingness of customers who voluntarily and actively show behavior to help other customers in the service process available at the bank. Conscientiousness is the behavior of customers who voluntarily comply with rules or regulations set by the bank in relation to its transaction services. Courtesy is the polite attitude or behavior shown by customers when making transactions and using the services available at the bank. Civic virtue is the attitude or behavior of customers to maintain the image of the bank or actively participate in activities carried out by the bank.

The emergence of CCB in customers can be influenced by bank employees' SOCB, which can in turn build customer trust to maintain relationships with the bank for a long period of time and will make customers willing to display behavior beyond their role (i.e., customer citizenship behavior), thus certainly benefitting the bank as an organization.

\section{HYPOTHESES}

Research conducted by Wu and Liao (2016) concluded that SOCB positively influences customer perceptions of the service quality provided by the company. Thus, the employees' quality-oriented work behavior relating to customers will lead to customer assessments of perceived service quality. Therefore, SOCB needs to be developed in employees so that companies can improve the service quality provided to customers.

Employees displaying SOCB can be identified from the level of commitment to the services they provide to customers. They feel happy when undertaking tasks to provide services to customers because their involvement in helping customers is the best part of the job for them. They feel proud if they can provide the best service to customers and leave them feeling satisfied (Wang, 2015). Payne and Webber (2006) found that altruism is the main dimension of SOCB, which is reflected in the willingness of employees to provide services beyond the basic standards and strive to satisfy customers.

Research conducted by Wang (2015) revealed that positive customer service-oriented work 
behavior by banks can be fostered by a strong learning climate in the organization. Banks can build SOCB by having a role model that provides an example of SOCB. In addition, employees are encouraged to be willing to share their knowledge and skills to educate customers about products and services provided by the bank. The organizational citizenship behavior which is oriented on technology-based service has an effect on the efficiency of individual tasks. It is therefore important to study customer-oriented organizational citizenship behavior more specifically in relation to the service behavior of individuals working in information technology (Deng \& Wang, 2014).

In their research, Auh, Menguc and Jung (2014) outlined that developing SOCB in employees, especially frontline employees, is part of the role and function of the leaders. The empowerment and the creation of a learning climate about customers will also lead to the formation of SOCB. The implementation of empowering leadership will provide employees with space and flexibility in serving customers as well as authority to provide services beyond standards that eventually lead to customer satisfaction.

The results of research conducted by Jehanzeb and Mohanty (2019) show that organizational justice has no significant relationship with organizational citizenship behavior, but that it does have a significant relationship with organizational commitment. Their results also confirmed that organizational commitment fully mediates the relationship between organizational justice and organizational citizenship behavior. In addition, power distance was found to moderate the relationship between organizational justice and organizational commitment. According to Yadav, Rangnekar and Srivastava (2019), the quality of work life has a positive influence on organizational citizenship behavior. Gender and type of organization moderate the relationship between the quality of work life and organizational citizenship behavior.

Based on the research conducted by Bove, Pervan, Beatty and Shiu (2009), CCB includes actions such as positive word-of-mouth (beneficial informal communication about aspects of the organization), affiliation relationships (using real features or personal items to communicate relationships with the organization), suggestions for improvements to services (not related to specific consumption examples), customer policing (ensuring appropriate behavior), voicing behavior (communicating service failures to organizations for the purpose of improvement), being flexible (willingness to adapt to the situation), good service actions (charity), facilitating and taking part in organizational activities (such as research or other sponsored activities).

Research conducted by Anaza and Zhao (2013) showed that customer satisfaction can affect CCB. Customers who are satisfied with the company tend to believe that the company has fulfilled its contractual obligation to provide them with excellent service. Therefore, customers might want to return the favor by being involved in customer citizenship behavior. Furthermore, in their research Nguyen, Groth, Walsh and Hennig-Thurau (2014) found that there are interrelated interactions between service quality and customer citizenship behavior. Good service quality will tend to generate intention to return and provide feedback. We therefore hypothesize that:

H1: Service-oriented organizational citizenship behavior (SOCB) has a significant positive effect on service quality from the perspective of customers/respondents of BPD Bank, whose employees are given training, compared to BPR Bank, whose employees are not given training.

$\mathrm{H}$ 2: There are differences in SOCB, service quality, and customer citizenship behavior (CCB) between BPD Bank and BPR Bank. 
FIGURE 1. Research model

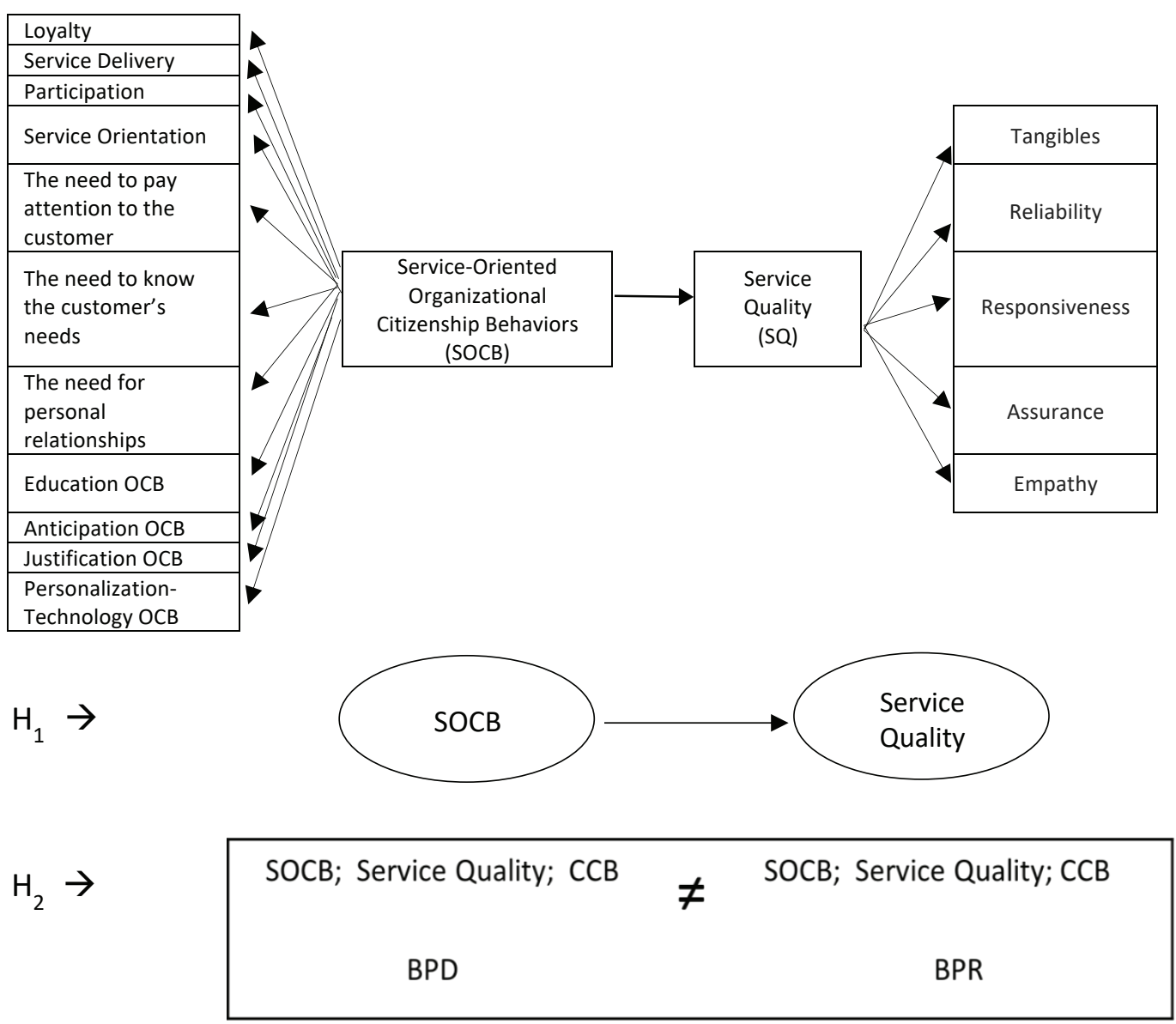

\section{RESEARCH METHODOLOGY}

\subsection{Sample frame and data collection}

The population of this study consists of the customers of Bank Pembangunan Daerah (BPD) and Bank Perkreditan Rakyat (BPR). The sample includes customers of six BPD branch offices and customers of BPR. The questionnaire was distributed to 170 BPD customers selected by 30 employees who attended the training and 101 BPR customers, totaling 271 respondents.

\subsection{Measurement}

The data used in this study were obtained from a questionnaire referring to the dimensions of service quality developed by Parasuraman et al. (1988), the SOCB dimensions developed by Sabiote and Roman (2005), as well as customer citizenship behavior. To measure the responses using the research instrument, a six-point Likert scale was used, where 1 = strongly disagree (SD); 2 = disagree (D); 3 = slightly disagree (SLD); $4=$ slightly agree $(S L A) ; 5=$ agree $(A) ; 6=$ strongly agree (SA).

\subsection{Research process and data analysis techniques}

The research process and data analysis techniques were as follows:

1. Conducting employee engagement, SOCB, and service quality training for BPD employees. 
2. Distributing questionnaires to BPD customers to allow them to assess the SOCB and service quality of employees who had attended training, and distributing questionnaires to funding customers at BPR.

3. Testing the effect of SOCB on service quality at BPD and BPR.

4. Analyzing data, which includes descriptive analysis and statistical analysis. The data analysis in this study was carried out using simple linear regression, with the two independent samples being compared using the Mann-Whitney test via the SPSS program.

\section{RESULTS}

\subsection{Sample characteristics}

The following describes the characteristics of respondents surveyed at the two banks. The total number of BPD customer respondents was 170, of whom 87 (51\%) were male and 83 (49\%) were female. In terms of age, 62 respondents
(37\%) were 25 to 35 years old (the largest category), with 8 respondents (5\%) aged between 55 and 65 (the smallest category). With respect to education, out of 170 respondents, 88 (52\%) held bachelor's degrees (the largest category) and 11 (7\%) held associate degrees (the smallest category).

The total number of BPR customer respondents was 101, of whom 56 (55\%) were female and 45 (45\%) were male. With respect to age, 35 respondents (34\%) were 35 to 45 years old (the largest category) and 7 (7\%) respondents were over 65 years old (the smallest category). In terms of education, 58 respondents (57\%) held bachelors' degrees (the largest category) and one (1\%) respondent had a doctorate (the smallest category). Regarding their current profession, of the 170 BPD customer respondents, 63 (37\%) were private company employees (the largest category) and 3 (2\%) were professionals (smallest category). The characteristics of the sample participating in the research at the two banks are presented in Table 1.

TABLE 1: Characteristics of BPD and BPR customer respondents

\begin{tabular}{|l|c|c|c|c|c|c|c|c|c|c|c|c|c|c|}
\hline \multicolumn{5}{|c|}{ Gender } & \multicolumn{5}{c|}{ Age } & \multicolumn{4}{c|}{ Education } \\
\hline Note & \multicolumn{1}{|c|}{ BPD } & \multicolumn{1}{c|}{ BPR } & Note & \multicolumn{2}{c|}{ BPD } & \multicolumn{2}{c|}{ BPR } & \multicolumn{2}{c|}{ Note } & \multicolumn{2}{c|}{ BPD } & \multicolumn{2}{c|}{ BPR } \\
\hline Male & 87 & $51 \%$ & 45 & $45 \%$ & $15-25$ & 31 & $18 \%$ & 13 & $13 \%$ & high school & 56 & $33 \%$ & 24 & $24 \%$ \\
\hline Female & 83 & $49 \%$ & 56 & $55 \%$ & $>25-35$ & 62 & $37 \%$ & 14 & $14 \%$ & $\begin{array}{l}\text { associate } \\
\text { degree }\end{array}$ & 11 & $7 \%$ & 11 & $11 \%$ \\
\hline & & & & & $>35-45$ & 43 & $25 \%$ & 35 & $34 \%$ & $\begin{array}{l}\text { bachelor's } \\
\text { degree }\end{array}$ & 88 & $52 \%$ & 58 & $57 \%$ \\
\hline & & & & & $>45-55$ & 26 & $15 \%$ & 21 & $21 \%$ & $\begin{array}{l}\text { master's } \\
\text { degree }\end{array}$ & 15 & $9 \%$ & 7 & $7 \%$ \\
\hline & & & & & $>55-65$ & 8 & $5 \%$ & 11 & $11 \%$ & doctorate & 0 & $0 \%$ & 1 & $1 \%$ \\
\hline Total & 170 & $100 \%$ & 101 & $100 \%$ & & 170 & $100 \%$ & 101 & $100 \%$ & & 170 & $100 \%$ & 101 & $100 \%$ \\
\hline
\end{tabular}

Source: Authors' own results.

The following are the results of the training given to BPD employees, which indicate that this training reached the second level of effective- ness, demonstrating an increase in knowledge after the training for most participants. Pre-test and post-test results are provided in Table 2. 
TABLE 2: Overview of pre-test and post-test training results

\begin{tabular}{|c|c|c|c|c|c|c|c|c|c|}
\hline $\begin{array}{c}\text { Partici- } \\
\text { pant } \\
\text { number }\end{array}$ & $\begin{array}{c}\text { Pre- } \\
\text { test }\end{array}$ & $\begin{array}{c}\text { Post- } \\
\text { test }\end{array}$ & Change & $\%$ & $\begin{array}{c}\text { Partici } \\
\text { pant } \\
\text { number }\end{array}$ & $\begin{array}{c}\text { Pre- } \\
\text { test }\end{array}$ & $\begin{array}{c}\text { Post- } \\
\text { test }\end{array}$ & Change & $\%$ \\
\hline 1 & 2.92 & 4.00 & 1.08 & $27 \%$ & 16 & 3.13 & 3.00 & -0.13 & $-4 \%$ \\
\hline 2 & 3.02 & 3.98 & 0.96 & $24 \%$ & 17 & 2.77 & 3.58 & 0.81 & $23 \%$ \\
\hline 3 & 3.44 & 3.58 & 0.13 & $4 \%$ & 18 & 2.69 & 3.00 & 0.31 & $10 \%$ \\
\hline 4 & 3.13 & 4.00 & 0.87 & $22 \%$ & 19 & 2.77 & 3.48 & 0.71 & $20 \%$ \\
\hline 5 & 3.17 & 3.10 & -0.08 & $-2 \%$ & 20 & 3.19 & 3.37 & 0.17 & $5 \%$ \\
\hline 6 & 2.98 & 3.00 & 0.02 & $1 \%$ & 21 & 2.90 & 3.31 & 0.40 & $12 \%$ \\
\hline 7 & 3.00 & 3.94 & 0.94 & $24 \%$ & 22 & 2.85 & 3.88 & 1.04 & $27 \%$ \\
\hline 8 & 3.38 & 4.00 & 0.62 & $15 \%$ & 23 & 2.44 & 3.21 & 0.77 & $24 \%$ \\
\hline 9 & 2.81 & 3.00 & 0.19 & $6 \%$ & 24 & 2.88 & 3.40 & 0.52 & $15 \%$ \\
\hline 10 & 3.54 & 4.00 & 0.46 & $12 \%$ & 25 & 2.54 & 2.75 & 0.21 & $8 \%$ \\
\hline 11 & 3.33 & 3.10 & -0.23 & $-7 \%$ & 26 & 3.00 & 4.00 & 1.00 & $25 \%$ \\
\hline 12 & 3.51 & 3.79 & 0.28 & $7 \%$ & 27 & 3.81 & 4.00 & 0.19 & $5 \%$ \\
\hline 13 & 2.71 & 2.87 & 0.15 & $5 \%$ & 28 & 3.50 & 3.90 & 0.40 & $10 \%$ \\
\hline 14 & 3.31 & 3.40 & 0.10 & $3 \%$ & 29 & 3.57 & 3.75 & 0.18 & $5 \%$ \\
\hline 15 & 2.77 & 3.35 & 0.58 & $17 \%$ & 30 & 3.54 & 3.42 & -0.12 & $-3 \%$ \\
\hline
\end{tabular}

Source: Authors' own results.

According to the results, 28 of the 30 participants (93\%) showed an increase in scores after training on SOCB-related material. With regard to the two remaining participants, there was a slight (non-significant) decrease in the average score, but with no decrease in the category (scores remained in the "adequate" category for participant No 16 and in the "good" category for participant No 30). In general, there was a 15\% increase in scores, from 2.97 ("sufficient") to 3.47 ("good").

It can be concluded that training on SOCB-related material enabled participants to reach the second level of effectiveness. Likewise, in training on material related to service quality, there was an increase in scores for 25 participants, or $83.3 \%$ of the sample. Four participants (16.6\%) showed a decrease in average scores: participant No 5 (from a score of 3.73 to 3.14), No 11 (from a score of 3.77 to 3.00), No 16 (from a score of 3.27 to 3.00) and No 25 (from a score of 2.95 to 2.77$)$. In general, an $8 \%$ increase in scores was observed, from a score of 3.25 ("good") to 3.55 ("good"). Therefore, it can be concluded that training on material related to service quality enabled participants to reach the second level of effectiveness.

\subsection{Description of $\mathrm{SOCB}$, service quality and CCB behavior at BPD and BPR}

Based on Table 3 results of the responses BPD Bank customers to the SOCB variable, the overall average SOCB value was 4.98 on a six-point scale, in the category of "agree" for the SOCB indicators perceived while interacting with BPD Bank.

The responses of customer respondents to the SOCB variable at BPR Bank showed an average value of 5.65 on a six-point scale, in the category of "strongly agree" for the SOCB indicators perceived while interacting with staff at that bank. This value is greater than the corresponding value for BPD Bank. 
TABLE 3: Customer respondents' responses to the SOCB variable

\begin{tabular}{|c|c|c|c|c|c|c|c|}
\hline \multicolumn{4}{|c|}{ BPD } & \multicolumn{4}{|c|}{ BPR } \\
\hline $\begin{array}{l}\text { Statement } \\
\text { items }\end{array}$ & Sum & Mean & Category & $\begin{array}{c}\text { Statement } \\
\text { items }\end{array}$ & Sum & Mean & Category \\
\hline L1_1 & 891 & 5.25 & SA & & 541 & 5.35 & SA \\
\hline L2_2 & 897 & 5.27 & SA & & 541 & 5.35 & SA \\
\hline L3_3 & 835 & 4.91 & $A$ & & 526 & 5.20 & SA \\
\hline L4_4 & 862 & 5.07 & $A$ & & 529 & 5.23 & SA \\
\hline L5_5 & 885 & 5.20 & SA & & 530 & 5.24 & SA \\
\hline \multicolumn{2}{|c|}{ Average L } & 4.09 & SLA & \multicolumn{2}{|c|}{ Average L } & 5.28 & SA \\
\hline SD1_6 & 915 & 5.38 & SA & & 534 & 5.28 & SA \\
\hline SD2_7 & 882 & 5.18 & SA & & 526 & 5.20 & SA \\
\hline SD3_8 & 871 & 5.12 & $A$ & & 536 & 5.30 & SA \\
\hline SD4_9 & 874 & 5.14 & A & & 539 & 5.33 & SA \\
\hline SD5_10 & 881 & 5.18 & SA & & 536 & 5.30 & SA \\
\hline SD6_11 & 893 & 5.25 & SA & & 533 & 5.27 & SA \\
\hline SD7_12 & 902 & 5.30 & SA & & 531 & 5.25 & SA \\
\hline SD8_13 & 902 & 5.30 & SA & & 538 & 5.32 & SA \\
\hline \multicolumn{2}{|c|}{ Average SD } & 5.23 & SA & \multicolumn{2}{|c|}{ Average SD } & 5.28 & SA \\
\hline SO1_14 & 881 & 5.18 & SA & & 535 & 5.29 & SA \\
\hline SO2_15 & 868 & 5.10 & $A$ & & 531 & 5.25 & SA \\
\hline SO3_16 & 868 & 5.13 & A & & 532 & 5.26 & SA \\
\hline SO4_17 & 877 & 5.15 & SA & & 528 & 5.22 & SA \\
\hline SO5_18 & 869 & 5.11 & A & & 526 & 5.20 & SA \\
\hline \multicolumn{2}{|c|}{ Average SO } & 5.13 & $A$ & \multicolumn{2}{|c|}{ Average SO } & 5.25 & SA \\
\hline A1_19 & 851 & 5.00 & $A$ & & 529 & 5.23 & SA \\
\hline A2_20 & 858 & 5.04 & A & & 533 & 5.27 & SA \\
\hline A3_21 & 876 & 5.15 & A & & 519 & 5.13 & $A$ \\
\hline A4_22 & 827 & 4.86 & $A$ & & 503 & 4.98 & $A$ \\
\hline A5_23 & 869 & 5.11 & A & & 525 & 5.19 & SA \\
\hline A6_24 & 856 & 5.03 & A & & 523 & 5.17 & SA \\
\hline \multicolumn{2}{|c|}{ Average A } & 5.03 & A & \multicolumn{2}{|c|}{ Average A } & 5.16 & SA \\
\hline NAC1_25 & 856 & 5.03 & $\mathrm{~A}$ & & 519 & 5.13 & A \\
\hline NAC2_26 & 860 & 5.05 & $A$ & & 518 & 5.12 & A \\
\hline NAC3_27 & 864 & 5.08 & A & & 525 & 5.19 & SA \\
\hline NAC4_28 & 848 & 4.98 & A & & 531 & 5.25 & SA \\
\hline \multicolumn{2}{|c|}{ Average NAC } & 5.04 & A & \multicolumn{2}{|c|}{ Average NAC } & 5.18 & SA \\
\hline NKCN1_29 & 853 & 5.01 & A & & 525 & 5.19 & SA \\
\hline NKCN2_30 & 851 & 5.00 & A & & 520 & 5.14 & A \\
\hline NKCN3_31 & 819 & 4.81 & A & & 513 & 5.07 & A \\
\hline \multicolumn{2}{|c|}{ Average NKCN } & 4.94 & A & \multicolumn{2}{|c|}{ Average NKCN } & 514 & A \\
\hline NRP1_32 & 838 & 4.92 & A & & 518 & 5.12 & A \\
\hline NRP2_33 & 856 & 5.05 & $A$ & & 523 & 5.17 & SA \\
\hline \multicolumn{2}{|c|}{ Average NRP } & 4.98 & A & \multicolumn{2}{|c|}{ Average NRP } & 5.15 & SA \\
\hline EOCB_34 & 867 & 5.1 & A & & 529 & 5.23 & SA \\
\hline
\end{tabular}




\begin{tabular}{|c|c|c|c|c|c|c|c|}
\hline \multicolumn{4}{|c|}{ BPD } & \multicolumn{4}{|c|}{ BPR } \\
\hline $\begin{array}{l}\text { Statement } \\
\text { items }\end{array}$ & Sum & Mean & Category & $\begin{array}{l}\text { Statement } \\
\text { items }\end{array}$ & Sum & Mean & Category \\
\hline AOCB_35 & 874 & 5.14 & A & & 527 & 5.21 & SA \\
\hline JOCB_1_36 & 864 & 5.08 & A & & 530 & 5.24 & SA \\
\hline JOCB_2_37 & 857 & 5.04 & $A$ & & 527 & 5.21 & SA \\
\hline PTOCB_38 & 858 & 5.04 & A & & 524 & 5.18 & SA \\
\hline Al_1_39 & 859 & 5.05 & $A$ & & 524 & 5.18 & SA \\
\hline Al_2_40 & 861 & 5.06 & A & & 530 & 5.24 & SA \\
\hline Al_3_41 & 850 & 5 & A & & 530 & 5.24 & SA \\
\hline Al_4_42 & 882 & 5.18 & SA & & 538 & 5.32 & SA \\
\hline \multicolumn{2}{|c|}{ Average Al } & 5.07 & A & \multicolumn{2}{|c|}{ Average Al } & 5.25 & SA \\
\hline \multicolumn{2}{|c|}{$\begin{array}{l}\text { Average value of the } \\
\text { SOCB variable }\end{array}$} & 4.98 & $S$ & \multicolumn{2}{|c|}{$\begin{array}{c}\text { Average value of the } \\
\text { SOCB variable }\end{array}$} & 5.65 & SA \\
\hline
\end{tabular}

Source: Authors' own results.

The overall average value of service quality was 5.15 on a six-point scale, in the category of "agree" for the service quality indicators perceived while interacting with BPD Bank. This is greater than the value obtained in the assessment of BPR respondents (see Table 4 below).
Table 4 also shows the customer respondents' responses to the service quality variable at BPR. Overall, the average value was 5.13 on a six-point scale, in the category of "agree" for the service quality indicators perceived while interacting with staff at BPR. This score was lower than the corresponding figure for BPD.

TABLE 4: Customer respondents' responses to the variable of service quality

\begin{tabular}{|c|c|c|c|c|c|c|c|}
\hline \multicolumn{4}{|c|}{ BPD } & \multicolumn{4}{|c|}{ BPR } \\
\hline $\begin{array}{c}\text { Statement } \\
\text { item }\end{array}$ & Sum & Mean & Category & $\begin{array}{c}\text { Statement } \\
\text { item }\end{array}$ & Sum & Mean & Category \\
\hline ta1 & 860 & 5.05 & A & & 487 & 4.82 & A \\
\hline ta2 & 856 & 5.03 & A & & 495 & 4.90 & A \\
\hline ta3 & 902 & 5.30 & SA & & 504 & 4.99 & $A$ \\
\hline \multicolumn{2}{|c|}{ Average tangible (ta) } & 5.13 & $A$ & & & 4.90 & A \\
\hline ri5 & 873 & 5.13 & A & & 514 & 5.08 & A \\
\hline ri6 & 868 & 5.10 & A & & 518 & 5.12 & A \\
\hline ri7 & 886 & 5.21 & SA & & 521 & 5.15 & SA \\
\hline ri8 & 873 & 5.13 & $A$ & & 521 & 5.15 & SA \\
\hline ri9 & 880 & 5.17 & SA & & 521 & 5.15 & SA \\
\hline \multicolumn{2}{|c|}{ Average reliability (ri) } & 5.15 & A & \multicolumn{2}{|c|}{ Average reliability (ri) } & 5.13 & A \\
\hline rs10 & 877 & 5.15 & A & & 524 & 5.18 & SA \\
\hline rs11 & 877 & 5.15 & $A$ & & 531 & 5.25 & SA \\
\hline rs12 & 889 & 5.22 & SA & & 531 & 5.25 & SA \\
\hline rs13 & 857 & 5.04 & $A$ & & 517 & 5.11 & $A$ \\
\hline \multicolumn{2}{|c|}{$\begin{array}{c}\text { Average } \\
\text { responsiveness (rs) }\end{array}$} & 5.14 & A & \multicolumn{2}{|c|}{$\begin{array}{c}\text { Average } \\
\text { responsiveness (rs) }\end{array}$} & 5.19 & SA \\
\hline as14 & 885 & 5.20 & SA & & 530 & 5.24 & SA \\
\hline
\end{tabular}




\begin{tabular}{|c|c|c|c|c|c|c|c|}
\hline \multicolumn{4}{|c|}{ BPD } & \multicolumn{4}{|c|}{ BPR } \\
\hline $\begin{array}{l}\text { Statement } \\
\text { item }\end{array}$ & Sum & Mean & Category & $\begin{array}{l}\text { Statement } \\
\text { item }\end{array}$ & Sum & Mean & Category \\
\hline as15 & 906 & 5.32 & SA & & 529 & 5.23 & SA \\
\hline as16 & 903 & 5.31 & SA & & 533 & 5.27 & SA \\
\hline as17 & 881 & 5.18 & SA & & 527 & 5.21 & SA \\
\hline \multicolumn{2}{|c|}{ Average assurance (as) } & 5.25 & SA & \multicolumn{2}{|c|}{ Average assurance (as) } & 5.23 & SA \\
\hline em18 & 860 & 5.05 & A & & 529 & 5.23 & SA \\
\hline em19 & 880 & 5.17 & A & & 536 & 5.30 & SA \\
\hline em20 & 851 & 5.00 & $A$ & & 520 & 5.14 & $A$ \\
\hline em21 & 878 & 5.16 & SA & & 525 & 5.19 & SA \\
\hline em22 & 852 & 5.01 & $A$ & & 525 & 5.19 & SA \\
\hline \multicolumn{2}{|c|}{ Average empathy (em) } & 5.08 & A & \multicolumn{2}{|c|}{ Average empathy (em) } & 5.21 & SA \\
\hline \multicolumn{2}{|c|}{$\begin{array}{c}\text { Average value of the } \\
\text { service quality variable }\end{array}$} & 5.15 & A & \multicolumn{2}{|c|}{$\begin{array}{l}\text { Average value of the } \\
\text { service quality variable }\end{array}$} & 5.13 & A \\
\hline
\end{tabular}

Source: Authors' own results.

When it comes to the overall average value of CCB quality, its score was 5.04 on a six-point scale, in the category of "agree" for the CCB indicators perceived by customers while interacting with staff at BPD Bank. The customer respondents' average score for the CCB variable at BPR was 5.33 on a six-point scale, in the category of "strongly agree" for the CCB indicators perceived while interacting with BPR Bank. This was greater than the corresponding score for BPD Bank, as shown in Table 5 below.

TABLE 5: Customer respondents' responses to the CCB variable

\begin{tabular}{|c|c|c|c|c|c|c|c|}
\hline \multicolumn{4}{|c|}{ BPD } & \multicolumn{4}{|c|}{ BPR } \\
\hline $\begin{array}{l}\text { Statement } \\
\text { items }\end{array}$ & Sum & Mean & Category & $\begin{array}{c}\text { Statement } \\
\text { items }\end{array}$ & Sum & Mean & Category \\
\hline ccb1 & 902 & 5.30 & SA & & 529 & 5.23 & SA \\
\hline ccb2 & 881 & 5.18 & SA & & 530 & 5.24 & SA \\
\hline ccb3 & 858 & 5.04 & A & & 519 & 5.13 & $A$ \\
\hline ccb4 & 883 & 5.19 & SA & & 526 & 5.20 & SA \\
\hline ccb5 & 820 & 4.82 & SLA & & 517 & 5.11 & $A$ \\
\hline ccb6 & 858 & 5.04 & $A$ & & 524 & 5.18 & SA \\
\hline \multicolumn{2}{|c|}{ Average ccb } & 5.1 & $A$ & \multicolumn{2}{|c|}{ Average ccb } & 5.18 & SA \\
\hline $\mathrm{fb} 1$ & 893 & 5.25 & SA & & 527 & 5.21 & SA \\
\hline $\mathrm{fb} 2$ & 833 & 4.9 & $A$ & & 516 & 5.10 & $A$ \\
\hline \multicolumn{2}{|c|}{ Average fb } & 5.07 & $A$ & \multicolumn{2}{|c|}{ Average fb } & 5.15 & SA \\
\hline a1 & 888 & 5.22 & SA & & 524 & 5.18 & SA \\
\hline $\mathrm{a} 2$ & 885 & 5.20 & SA & & 527 & 5.21 & SA \\
\hline a3 & 890 & 5.23 & SA & & 527 & 5.21 & SA \\
\hline a4 & 904 & 5.31 & SA & & 538 & 5.32 & SA \\
\hline \multicolumn{2}{|c|}{ Average a } & 5.24 & SA & \multicolumn{2}{|c|}{ Average a } & 5.98 & SA \\
\hline h1 & 766 & 4.50 & $A$ & & 514 & 5.08 & $A$ \\
\hline h2 & 839 & 4.93 & $A$ & & 521 & 5.15 & SA \\
\hline
\end{tabular}




\begin{tabular}{|c|c|c|c|c|c|c|c|}
\hline \multicolumn{4}{|c|}{ BPD } & \multicolumn{4}{|c|}{ BPR } \\
\hline $\begin{array}{c}\text { Statement } \\
\text { items }\end{array}$ & Sum & Mean & Category & $\begin{array}{c}\text { Statement } \\
\text { items }\end{array}$ & Sum & Mean & Category \\
\hline h3 & 855 & 5.02 & A & & 528 & 5.22 & SA \\
\hline h4 & 857 & 5.04 & A & & 527 & 5.21 & SA \\
\hline \multicolumn{2}{|c|}{ Average $\mathrm{h}$} & 4.87 & A & \multicolumn{2}{|c|}{ Average h } & 5.16 & SA \\
\hline t1 & 819 & 4.81 & A & & 524.00 & 5.18 & SA \\
\hline t2 & 842 & 4.95 & A & & 519.00 & 5.13 & $A$ \\
\hline t3 & 848 & 4.98 & A & & 529.00 & 5.23 & SA \\
\hline \multicolumn{2}{|c|}{ Average t } & 4.91 & A & \multicolumn{2}{|c|}{ Average t } & 5.18 & SA \\
\hline \multicolumn{2}{|c|}{$\begin{array}{c}\text { Average value of the } \\
\text { CCB variable }\end{array}$} & 5.04 & A & \multicolumn{2}{|c|}{$\begin{array}{c}\text { Average value of the } \\
\text { CCB variable }\end{array}$} & 5.33 & SA \\
\hline
\end{tabular}

Source: Authors' own results.

\subsection{SOCB effect on service quality at BPD and BPR}

Table 6 sets out the results of the SPSS output related to the model summary and linear regression coefficients for BPD.
The correlation between SOCB and service quality at BDP is 0.852 . The R-square value of 0.727 indicates that $72.7 \%$ of the variance in service quality may be explained by SOCB, while the rest is influenced by other factors.

TABLE 6: Model summary

\begin{tabular}{|c|c|c|c|c|c|c|c|c|}
\hline \multirow{2}{*}{ Model } & \multirow{2}{*}{$\mathbf{R}$} & \multirow{2}{*}{$\begin{array}{c}\mathbf{R} \\
\text { Square }\end{array}$} & $\begin{array}{c}\text { Adjusted } \mathbf{R} \\
\text { Square }\end{array}$ & $\begin{array}{c}\text { Std. Error of } \\
\text { the Estimate }\end{array}$ & $\begin{array}{c}\text { Change Statistics } \\
\text { R Square } \\
\text { Change }\end{array}$ & $\begin{array}{c}\text { F } \\
\text { Change }\end{array}$ & df1 & df2 \\
\hline 1 & $.852_{2}$ & .727 & .725 & .22574 & .727 & 446.637 & 1 & 168 \\
\hline
\end{tabular}

a. Predictor: (Constant), SQ

b. Dependent Variable: SOCB

Source: Authors' own results.

TABLE 7: Coefficients

\begin{tabular}{|l|c|c|c|c|c|}
\hline \multirow{3}{*}{ Model } & \multicolumn{2}{|c|}{$\begin{array}{c}\text { Unstandardized } \\
\text { coefficients }\end{array}$} & $\begin{array}{c}\text { Standardized } \\
\text { coefficients }\end{array}$ & \multirow{2}{*}{ T } & \multirow{2}{*}{ Sig. } \\
\cline { 2 - 6 } & B & Std. Error & Beta & & \\
\hline 1 (Constant) & .719 & .208 & & 3.457 & .001 \\
SQ & .851 & .040 & .852 & 21.134 & .000 \\
\hline
\end{tabular}

a. Dependent Variable: SOCB

Source: Authors' own results.

Based on the data provided in Table 7, it can be concluded that SOCB has an effect on service quality at BPD. This is indicated by the significance value of 0.00 ( $p<0.05)$. Thus, the hypothesis stating that SOCB has a significant positive effect on service quality can be accepted. The regression model is $Y=0.719+0.851 X$.

Table 8 sets out the results of the SPSS output related to the model summary and linear regression coefficients for BPR. 
TABLE 8: Model summary

\begin{tabular}{|c|c|c|c|c|c|c|c|c|}
\hline \multirow{2}{*}{ Model } & \multirow{2}{*}{$\mathbf{R}$} & \multirow{2}{*}{$\begin{array}{c}\mathbf{R} \\
\text { Square }\end{array}$} & $\begin{array}{c}\text { Adjusted R } \\
\text { Square }\end{array}$ & $\begin{array}{c}\text { Std. Error of } \\
\text { the Estimate }\end{array}$ & $\begin{array}{c}\text { R Square } \\
\text { Change }\end{array}$ & $\begin{array}{c}\text { F } \\
\text { Change }\end{array}$ & df1 & df2 \\
\hline 1 & .875 & .766 & .764 & .23410 & .766 & 323.996 & 1 & 99 \\
\hline
\end{tabular}

a. Predictor: (Constant), SQ

b. Dependent Variable: SOCB

Source: Authors' own results.

The value of $\mathrm{R}$ (the correlation between SOCB and service quality at BPR) is 0.875 . The R-square value of 0.766 indicates that $76.6 \%$ of the vari- ance in service quality SOCB may be explained by SOCB, while the rest is influenced by other factors.

TABLE 9: Coefficients

\begin{tabular}{|l|c|c|c|c|c|}
\hline \multirow{2}{*}{ Model } & \multicolumn{2}{|c|}{$\begin{array}{c}\text { Unstandardized } \\
\text { coefficients }\end{array}$} & $\begin{array}{c}\text { Standardized } \\
\text { coefficients }\end{array}$ & \multirow{2}{*}{ T } & \multirow{2}{*}{ Sig. } \\
\cline { 2 - 6 } & B & Std. Error & Beta & & \\
\hline 1 (Constant) & .983 & .237 & & 4.148 & .000 \\
SQ & .824 & .046 & .875 & 18.000 & .000 \\
\hline
\end{tabular}

a. Dependent Variable: SOCB

Source: Authors' own results.

Based on the data provided in Table 9, it can be concluded that SOCB has a significant effect on service quality at BPR. This is indicated by the significance value of $0.00(p<0.05)$. Thus, the hypothesis stating that SOCB has a significant positive effect on service quality can be accepted. The regression model is $Y=0.983+$ $0.824 X$

\subsection{SOCB difference test between BPD and BPR}

The average SOCB scores from customers for the two independent samples (BPD and BPR) were compared using the Mann-Whitney test. The results are shown in Table 10.

TABLE 10: Test statistics

\begin{tabular}{|l|c|}
\hline & SOCB \\
\hline Mann-Whitney U & $7.602 \mathrm{E} 3$ \\
Wilcoxon W & $2.214 \mathrm{E} 4$ \\
Z & -1.580 \\
Asymp. Sig (2-tailed) & .114 \\
\hline a. Grouping Variable: bank & \\
\hline
\end{tabular}

Source: Authors' own results.
With the Asymp. Sig. (2-tailed) value of 0.114 ( $p$ $>0.05)$, it can be concluded that there is no significant difference between BPD and BPR in the average value of customer respondents' SOCB assessments.

\subsection{Service quality difference test between BPD and BPR}

The results of the difference tests comparing average service quality scores assigned by customers in the two independent samples (BPD and BPR) are shown in Table 11.

TABLE 11: Test statistics

\begin{tabular}{|l|c|}
\hline & SQ \\
\hline Mann-Whitney U & $8.354 \mathrm{E} 3$ \\
Wilcoxon W & $1.350 \mathrm{E} 4$ \\
Z & -.373 \\
Asymp. Sig (2-tailed) & .709 \\
\hline \multicolumn{2}{|l|}{ a. Grouping Variable: bank } \\
\hline
\end{tabular}

Source: Authors' own results.

The results point to no significant difference in the average value of service quality for BPD 
and BPR, as assessed by customer respondents, because the Asymp Sig. (2-tailed) value is 0.709 $(p>0.05)$.

\subsection{Customer citizenship behavior (CCB) difference test between BPD and BPR}

The results of the difference test comparing average CCB scores for the two independent samples (BPD and BPR) are shown in Table 12.

\section{TABLE 12: Test statistics}

\begin{tabular}{|l|c|}
\hline & CCB \\
\hline Mann-Whitney U & $7.500 E 3$ \\
Wilcoxon W & $2.204 E 4$ \\
Z & -1.750 \\
Asymp. Sig (2-tailed) & .080 \\
\hline \multicolumn{2}{|l|}{ a. Grouping Variable: bank } \\
\hline
\end{tabular}

Source: Authors' own results.

With the Asymp Sig. (2-tailed) value of 0.080 ( $p>0.05)$, it can be concluded that there is no significant difference in the average CCB value as assessed by customer respondents between $B P D$, whose employees were given training, and BPR, whose employees were not given training.

\section{DISCUSSION}

The results of the research conducted at the two banks show that SOCB has a significant effect on service quality, as evidenced by the significance value of $0.00(p<0.05)$ at BPD and BPR. These results concur with those obtained in previous studies (Harsono, Prawitowati, Rachmat \& Widyantoro, 2020) and are in line with the results of the studies conducted by Wu and Liao (2016), Wang (2015), Deng and Wang (2014), and Auh and others (2014). The results confirm that developing good SOCB will improve service quality, especially in the aspects that are closely related to reliability, responsiveness, empathy, and assurance; in turn, this will have an impact on satisfaction and ultimately improve CCB.

There was no significant difference in the customer respondents' average scores for SOCB, service quality, or customer service behavior at BPD and BPR. This raises the question about the reasons for the absence of a difference in the results even though the customer respondents assessed SOCB, service quality, and customer service behavior at the two banks using different treatments, that is, at BPD, whose employees were given training, and BPR, whose employees were not given training. An analysis of the training results for BPD obtained before this research was conducted confirmed a change in employee behavior after attending the training (Harsono et al., 2020). Such findings are in line with the research conducted by Pham, Phan, Tučková, Vo and Nguyen (2018), which found that green training and organizational culture have a positive effect on organizational citizenship behavior regarding the environment.

To answer the question posed here, it is important to note that the operational sites of BPD and BPR are far apart, with no overlap in their respective regions. In addition, because these banks operate in different areas, they have different characteristics, which are influenced by their management style and organizational culture. They are also influenced by the local culture as well as by the acceptance of the local community/customers and their perception of the banks. The empirical findings indicate that there is no difference in SOCB, service quality, or customer service behavior between the bank whose employees were given training and the bank whose employees were not given training. However, from the aspect of the relationship between SOCB and service quality, both banks had the same result. But given that each has distinctive features because of their locality, they cannot be fully compared. In addition, from the aspect of book value, BPD is much bigger than BPR, and its area of operation and services are far more complex.

Although the results of this study prove that there is no difference in SOCB and service quality between BPD Bank and BPR Bank, it can be concluded that SOCB is closely related to service quality. This proves that both banks need to improve employee performance by increas- 
ing employee awareness of SOCB because of the correlation to service quality, especially its responsiveness, assurance, empathy, and reliability elements.

\section{CONCLUSION, LIMITATIONS, AND FUTURE RESEARCH}

At both banks, SOCB was found to have a significant influence on service quality. Therefore, both banks must develop good SOCB in order to improve the quality of services provided to customers, specifically in aspects that are closely related to employees, such as reliability, responsiveness, empathy, and assurance. In turn, customers who perceive the existence of SOCB and good service quality will respond with good CCB.

While statistical calculations confirmed the lack of significant differences in the average values of SOCB, service quality, and customer service behavior at the two banks, the fact is that they differ due to the organizational culture, management style, business scale, and their very locations, as well as the characteristics of the respondents. Nevertheless, it was demonstrated that training brings about an increase in employee skills and knowledge.

This study focuses on SOCB and service quality without examining the relationship between satisfaction and CCB, whereas, in theory, it should be considered. The sample size for the two banks was not equal and some changes were made with respect to the respondents who rated employees because certain employees who had attended the training retired. For future research, it is suggested that elements of organizational culture and local culture be included, since respondents have different characteristics in terms of local culture.

\section{References}

1. Anaza, N., \& Zhao, J. (2013). Encounter-based antecedents of e-customer citizenship behaviors. Journal of Services Marketing, 27(2), 130-140.

2. Auh, S., Menguc, B., \& Jung, Y. S. (2014). Unpacking the relationship between empowering leadership and service-oriented citizenship behaviors: A multilevel approach. Journal of the Academy of Marketing Science, 42, 558-570.

3. Bove, L. L., Pervan, S.J., Beatty, S. E., \& Shiu, E. (2009). Service worker role in encouraging customer organizational citizenship behaviors. Journal of Business Research, 62(7), 698-705.

4. Brady, M. K., \& Cronin, J. J. (2001). Some thought on conceptualizing perceived service quality: a hierarchical approach. Journal of Marketing, 65(3), 34-39.

5. Castro, C. M., Armario, E. M., \& Ruiz, D. M. (2004). The influence of employee organizational citizenship behavior on customer loyalty. International Journal of Service Industry Management, 15(1), 27-53.

6. Cronin, J. J., \& Taylor, S. A. (1992). Measuring service quality: A reexamination and extension. Journal of Marketing, 56, 55-68.

7. Daskalopoulou, I., \& A. Petrou. (2005). Service quality and store performance: Some evidence from Greece. Managing Service Quality, 15(1), 24-40.

8. de Jong, A., de Ruyter, K., \& Lemmink, J. (2005). Service Climate in Self-Managing Teams: Mapping the Linkage of Team Member Perceptions and Service Performance Outcomes in a Business-to-Business Setting. Journal of Management Studies, 42(8), 1593-1620.

9. Deng, X., \& Wang, T. (2014). Understanding post-implementation support for enterprise systems: an empirical study of its personnel's customer-oriented citizenship behaviors. Journal of Information Systems, 28(2), 17-39. 
10. Di, E., Huang, C-J., Chen, I-H., \& Yu, T-C. (2010). Organisational justice and customer citizenship behaviour of retail industries. The Service Industries Journal, 30(11), 1919-1934.

11. Garvin, D. A. (1984). What does 'product quality' really mean?. Sloan Management Review, 26, 25-43.

12. Gomez, M. I., McLaughlin, E. W., \& Wittink, D. R. (2004). Customer satisfaction and retail sales performance: An empirical investigation. Journal of Retailing, 80(4), 265-278.

13. Gronroos, C. (1984). A service quality model and its market implications. European Journal of Marketing, 18(4), 36-44.

14. Gronroos, C. (2000). Service management and marketing: A customer relationship management approach $\left(2^{\text {nd }}\right.$ ed.). West Sussex: John Wiley \& Sons.

15. Harsono, S., Prawitowati, T., Rachmat, B., \& Widyantoro, H. (2020). Mengembangkan service oriented-organizational citizenship behaviour (SOCB) dan Kualitas Layanan (Servqual). Jurnal Penamas Adibuana, 3(2), 63-72.

16. Harsono, S., Widyantoro, H., Prawitowati, T., \& Rachmat, B. (2017). The development of service quality model as a criterion in selecting the banks in Indonesia. Polish Journal of Management Studies, 15(2), 82-92.

17. Harsono, S., Widyantoro, H., Prawitowati, T., \& Rachmat, B. (2019). Perception, gap and reflection of S-OOCBs dimensions and their influence on Servqual from the perspective of banking employees and customers in Indonesia Religación. Revista de Ciencias Sociales, 5(3), 118-125.

18. Jain, A. K., Malhotra, N. K., \& Guan, C. (2012). Positive and negative affectivity as mediators of volunteerism and service-oriented citizenship behavior and customer loyalty. Psychology and Marketing, 29(12), 1004-1017.

19. Jalil, M. A., \& Rahman, M. K. (2014). The impact of Islamic branding on consumer preference towards Islamic banking services: An empirical investigation in Malaysia. Journal of Islamic Banking and Finance, 2(1), 209-229.

20. Jehanzeb, K., \& Mohanty, J. (2019). The mediating role of organizational commitment between organizational justice and organizational citizenship behavior: Power distance as moderator. Personnel Review, 49(2), 445-468.

21. Kumar, Y. L. N. (2014). Importance of organizational citizenship behaviors in enhancing customer service indicators: A review. IUP Journal of Management Research, 8(1), 17-28.

22. Nguyen, H., Groth, M., Walsh, G., \& Hennig-Thurau, T. (2014). The impact of service scripts on customer citizenship behavior and the moderating role of employee customer orientation. Psychology and Marketing, 31(12), 1096-1109.

23. O'Neill, M., \& Palmer, A. (2003). An exploratory study of the effects of experience on consumer perceptions of the service quality construct. Managing Service Quality, 13, 187-196.

24. Organ, D. W. (1988). Organizational Citizenship Behavior: The Good Solider Syndrome. Lexington, MA: Lexington Books.

25. Parasuraman, A., Zeithaml, V. A., \& Berry, L. L. (1988). SERVQUAL: A multiple-item scale for measuring consumer perceptions of service quality. Journal of Retailing, 65(1), 12-36.

26. Payne, S. C., \& Webber, S. S. (2006). Effects of service provider attitudes and employment status on citizenship behaviors and customers' attitudes and loyalty behavior. Journal of Applied Psychology, 91(2), 365-378.

27. Pham, N. T., Phan, Q. P. T., Tučková, Z., Vo, N., \& Nguyen, L. H. L. (2018). Enhancing the organizational citizenship behavior for the environment: the roles of green training and organizational culture. Management \& Marketing. Challenges for the Knowledge Society, 13(4), 1174-1189.

28. Rust, R. T., \& Oliver, R. L. (1994). Service quality: Insights and managerial implications from the frontier. New York, NY: Sage Publications. 
29. Ryan, A. M., \& Ployhart, R. E. (2003). Customer service behavior. In: W. C. Borman, D. R. Ilgen \& R. J. Klimoski (Eds.), Handbook of psychology: Industrial and organizational psychology, 12 (pp. 377-397). Hoboken: John Wiley \& Sons.

30. Sabiote, E. F., \& Roman, S. (2005). Organizational citizenship behavior from the service customer's perspective. International Journal of Market Research, 46(3), 317-336.

31. Schneider, B., Ehrhart, M. G., Mayer, D. M., Saltz, J. L., \& K. Niles-Jolly, K. (2005). Understanding organization-customer links in service settings. Academy of Management Journal, 48(6), 1017-1032.

32. Tjiptono, F., \& Chandra, G. (2011). Service, quality, \& satisfaction. Yogyakarta: Andi.

33. Wang, M. L. (2015). Learning climate and customer-oriented behaviors: the mediation of customer knowledge. Journal of Managerial Psychology, 30(8), 955-969.

34. Wu, P-H. \& Liao, J-F. (2016). Service-Oriented Organizational Citizenship Behavior, Perceived Service Quality and Customer Satisfaction in Hospitality Industry. Journal of Applied Sciences, 16(1), 18-24.

35. Yadav, M., Rangnekar, S., \& Srivastava, A. P. (2019). Demographic variables as moderators between QWL and OCB. Industrial and Commercial Training, 51(7/8), 396-408.

36. Zeithaml, V. A., \& Bitner, M. J. (2003). Services Marketing ( ${ }^{\text {rd }}$ ed.). Boston: McGraw Hill.

37. Zeithaml, V. A., Berry, L. L., \& Parasuraman, A. (1988). Communication and control processes in the delivery of service quality. Journal of Marketing, 52(2), 35-48.

38. Zeithaml, V. A., Parasuraman, A., \& Dan, L. L. B. (1990). Delivering quality services. New York, NY: Free Press. 